Wahana Didaktika Vol. 16 No.3 September 2018 : 346-353

\title{
PENGARUH STRATEGI WRITING IN THE HERE AND NOW TERHADAP KEMAMPUAN MENULIS ARGUMENTASI SISWA KELAS X SMK MADYATAMA PALEMBANG
}

\author{
Oleh: Hermansyah \\ (Dosen Universitas PGRI Palembang) \\ Email :anchahermansyah9@gmail.com
}

\begin{abstract}
Abstrak
Penelitian ini merupakan hasil penelitian tentang Pengaruh Strategi Writing In The Here and Now Terhadap Kemampuan Menulis Argumentasi Siswa Kelas X SMK Madyatama Palembang. Strategi writing in the here and merupakan bagian dari active learning yang diperkenalkan oleh Silberman. Tujuan penelitian ini adalah untuk mengetahui dan mendeskripsikan pengaruh strategi writing in the here and now terhadap kemampuan menulis argumentasi siswa kelas X SMK Madyatama Palembang.Populasi penelitian ini adalah seluruh siswa kelas $X$ SMK Madyatama Palembang. Sampel penelitian ini adalah kelas X TKJ 3 sebagai kelas eksperimen. Teknik data yang digunakan adalah tes dan dokumentasi. Dari hasil perhitungan statistik uji-t satu fihak, diperoleh nilai $t_{\text {hitung }}=3,50$ dan $t_{\text {tabel }} 1,6991$. Dengan demikian berarti $t_{\text {hitung }} \geq t_{\text {tabel }}$ sehingga $H_{0}$ ditolak dan $H_{a}$ diterima.Hal itu menunjukkan bahwa adanya pengaruh strategi writing in the here and now terhadap hasil belajar siswa pada materi karangan argumentasi di kelas X SMK Madyatama Palembang.
\end{abstract}

Kata Kunci: Writing in the Here and Now, Argumentasi

\section{THE EFFECT OF WRITING IN THE HERE AND NOW STRATEGY ON THE TENTH GRADE STUDENTS' ARGUMENTATION WRITING ABILITY OF MADYATAMA VOCATIONAL SCHOOL PALEMBANG}

\begin{abstract}
This research is the result of research about Influence of Writing Strategy in the Here and Now on Writing Ability of Argumentation of Grade X Student of SMK Madyatama Palembang. Strategy writing in the here and is part of the active learning that was introduced by Silberman. The purpose of this study is to know and describe the influence of writing strategy in the here and now to the ability to write argumentation of students of class X SMK Madyatama Palembang. Population of this research is all students of class $X$ SMK Madyatama Palembang. The sample of this research is class X TKJ 3 as experiment class. Data technique used is test and documentation. From the calculation of t-test statistic one side, obtained value $t_{-}$(count) $=3.50$ and $t_{-}$(table) 1.6991. Thus it means $t_{-}$(count) $\geq t_{-}$(table) so that it is rejected and accepted. It shows that the influence of writing in the here and now strategy on the learning result of students
\end{abstract}


Pengaruh Strategi Writing ...(Hermansyah)

in writing argumentative texts at tenth grade students of SMK Madyatama Palembang.

Keywords: Writing in the here and now, argumentation

\section{A. PENDAHULUAN}

Keterampilan menulis merupakan salah satu aspek kemampuan berbahasa dalam mengungkapkan ide, gagasan (pendapat) siswa berupa tulisan. Menulis merupakan bagian yang tidak terpisahkan dalam seluruh pembelajaran yang dialami siswa selama menuntut ilmu di sekolah. Menulis memerlukan keterampilan karena diperlukan latihan-latihan yang berkelanjutan, dan terus menerus terutama dalam mata pelajaran Bahasa Indonesia yang mencakup empat keterampilan berbahasa, yaitu (1) keterampilan menyimak, (2) keterampilan berbicara, (3) keterampilan membaca, (4) keterampilan menulis.

Di dalam dunia pendidikan, menulis akan tetap berharga, sebab menulis membantu seseorang berpikir lebih mudah. Menulis adalah suatu alat yang sangat ampuh dalam belajar yang dengan sendirinya memainkan peran yang sangat penting dalam dunia pendidikan (Kusumaningsih, dkk., 2013:65). Menurut Semi (2007:40), menulis merupakan suatu proses kreatif. Sejalan Armariena (2017:99) menyatakan bahwa kemampuan menulis adalah kemampuan yang bersifat aktif dan produktif di dalam menghasilkan tulisan yang diperoleh melalui proses pembelajaran dan latihan secara terus-menerus. Artinya, menulis itu merupakan sebuah keterampilan yang dilakukan melalui tahapan yang harus dikerjakan dengan mengerahkan keterampilan, seni, dan kiat sehingga semuanya berjalan dengan efektif.

Dengan demikian dapat disimpulkan bahwa menulis ialah suatu kegiatan yang menyampaikan maksud dan tujuannya melalui bahasa tulis agar dapat bermanfaat bagi pembaca. Jenis karangan yang tak kalah menariknya dengan karangan deskripsi, narasi, eksposisi, dan persuasi adalah karangan argumentasi.

Menurut Semi (2007:74), argumentasi adalah tulisan yang bertujuan menyakinkan atau membujuk pembaca tentang kebenaran pendapat penulis. Selanjutnya Armariena mengungkapkan argumentasi dalam prosesnya 
memerlukan data dan fakta untuk mendukung pendapat penulis (Armariena, 2015:370). Berdasarkan uraian di atas, dapat disimpulkan bahwa argumentasi merupakan jenis tulisan atau karangan yang bertujuan untuk meyakinkan pembaca tentang kebenaran atas pernyataan dari penulis didukung dengan data dan fakta.

Keterampilan menulis karangan argumentasi dalam pembelajaran bahasa Indonesia khususnya dalam Kurikulum Tingkat Satuan Pendidikan (KTSP) terdapat dalam Standar Kompetensi (SK) yaitu Berkomunikasi dengan bahasa Indonesia setara tingkat semenjana dengan kompetensi dasar (KD) Membuat berbagai teks tertulis dalam konteks bermasyarakat dengan memilih kata, bentuk kata, dan ungkapan yang tepat.

Maka dari itu, peneliti tertarik untuk menerapkan strategi Writing In The Here And Now pada menulis argumentasi. Strategi Writing In The Here And Now merupakan bagian dari Active Learning yang diperkenalkan oleh Silberman (2016) strategi Writing In The Here And Now merupakan sebuah cara dramatis untuk meningkatkan perenungan secara mandiri dengan meminta siswa menuliskan laporan tindakan kala ini (present tense) tentang sebuah pendapat yang akan mereka kemukakan. Berdasarkan uraian latar belakang serta batasan masalah di atas, maka rumusan masalah dalam penelitian ini adalah adakah pengaruh yang signifikan strategi pembelajaran Writing In The Here And Now terhadap kemampuan menulis argumentasi pada siswa kelas X SMK Madyatama Palembang.

\section{B. METODOLOGI PENELITIAN}

Paradigma dalam penelitian eksperimen model ini dapat digambarkan seperti berikut:

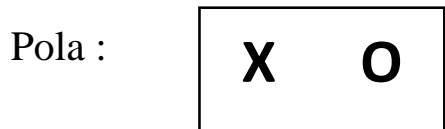

$\mathrm{X}=$ treatment yang diberikan (variabel independen)

$\mathrm{O}=$ Observasi (variabel dependen)

Paradigma itu dapat dibaca sebagai berikut: terdapat suatu kalimat suatu kelompok diberi treatment/ perlakuan, dan selanjutnya diobservasi hasilnya. 
Pengaruh Strategi Writing ...(Hermansyah)

Treatment adalah sebagai variabel independen, dan hasil hasil adalah variabel dependen (Sugiyono, 2016:110).

\section{Populasi dan Sampel}

Menurut Sugiyono (2016:117), populasi adalah wilayah generalisasi yang terdiri atas objek/subyek yang mempunyai kualitas dan karateristik tertentu yang ditetapkan oleh peneliti untuk dipelajari dan kemudian ditarik kesimpulannya. Populasi dari penelitian ini adalah seluruh siswa kelas X SMK Madyatama Palembang tahun 2016/2017 berjumlah 204 siswa.

Adapun teknik dari pengambilan sampel menggunakanSimple Random Sampling. Dikatakan simple (sederhana) karena pengambilan anggota sampel dari populasi dilakukan secara acak tanpa memperhatikan strata yang ada dalam populasi itu (Sugiyono, 2016:120). Berdasarkan pendapat di atas bahwa sampel dalam penelitian ini satu kelas eksperimen yaitu kelas X TKJ.3.

\section{Teknik Pengumpulan Data}

Adapun teknik pengumpulan data yang digunakan dalam penelitian ini disesuaikan dengan kebutuhan, sebagai berikut.

\section{Tes}

Tes digunakan untuk mengukur kemampuan siswa dalam menulis argumentasi baik sebelum pelaksanaan tindakan maupun sesudah pelaksanaan tindakan.

\section{Dokumentasi}

Dokumentasi digunakan sebagai pelengkap dari penggunaan metode observasi. Jenis dokumen yang digunakan dalam penelitian ini adalah foto-foto saat penelitian berlangsung

\section{Teknik Uji Coba Instrumen}

Sebelum tes diberikan kepada siswa sampel penelitian, penulis terlebih dahulu melakukan uji coba kepada siswa sampel untuk uji validitas. Adapun saran dari validator yaitu instrumen yang diujikan kepada peserta didik hanya satu soal, 
dan perbaiki rencana pelaksanaan pembelajaran (RPP) pada bagian apersepsi, serta elaborasi.Setelah dilakukan perbaikan maka instrumen sudah dikatakan baik dan dapat melakukan uji coba instrumen untuk mengetahui validitas soal yang dibuat.

\section{HASIL PENELITIAN DAN PEMBAHASAN}

\section{Hasil Analisis Data Tes Siswa}

Untuk mengetahui hasil belajar siswa maka diberikan soal tes pada kelas eksperimen. Dari soal tes inilah dapat diketahui deskripsi data hasil belajar siswa yang diajarkan menggunakan strategi writing in the here and now pada kelas eksperimen.

Dalam penelitian ini siswa yang menjadi kelas sampel adalah siswa kelas $X$ Teknik Komputer Jaringan (TKJ) 3 yang berjumlah 30 siswa. Tes yang diberikan berupa tes dengan bentuk tema karangan yang berjumlah 1 soal. Tes ini diberikan untuk melihat sejauh mana pemahaman siswa terhadap materi yang telah diajarkan dengan menggunakan strategi writing in the here and now. Adapun untuk mengetahui uji kenormalan data pada kelas eksperimen dapat dilihat pada analisis sebagai berikut:

\section{Kelas Eksperimen}

Berdasarkan analisis data hasil tes kelas eksperimen yang menggunakan strategi writing in the here and now dapat diketahui bahwa nilai tertingginya adalah 85 yang di dapat oleh 2 orang siswa dan nilai terendahnya adalah 40 yang di dapat oleh 2 orang siswa. Dari tabel 6 penilaian tes latihan pada kelas eksperimen yang menggunakan model ceramah (konvensional) dalam pelajaran karangan argumentasi dengan hasil tes latihan.

Setelah mendapatkan penilaian latihan yang berjumlah 1 soal, maka peneliti mendapatkan hasil akhir di kelas eksperimen yang menggunakan strategi writing in the here and now dengan nilai KKM 75. 
Tabel I

Distribusi Frekuensi Nilai Tes Akhir Kelas Eksperimen

\begin{tabular}{|c|c|c|c|c|c|}
\hline Interval Nilai Tes & $\boldsymbol{f}_{\boldsymbol{i}}$ & $\boldsymbol{x}_{\boldsymbol{i}}$ & $\boldsymbol{f}_{\boldsymbol{i}} \boldsymbol{x}_{\boldsymbol{i}}$ & $\boldsymbol{x}_{\boldsymbol{i}}{ }^{2}$ & $\boldsymbol{f}_{\boldsymbol{i}} \boldsymbol{x}_{\boldsymbol{i}}^{2}$ \\
\hline $71-73$ & 6 & 72 & 432 & 5184 & 31104 \\
\hline $74-76$ & 4 & 75 & 300 & 5625 & 22500 \\
\hline $77-79$ & 14 & 78 & 1092 & 6084 & 85176 \\
\hline $80-82$ & 1 & 81 & 81 & 6561 & 6561 \\
\hline $83-85$ & 3 & 84 & 252 & 7056 & 21168 \\
\hline $86-88$ & 2 & 87 & 174 & 7569 & 15138 \\
\hline Jumlah & 30 & 477 & 2331 & 38079 & 181647 \\
\hline
\end{tabular}

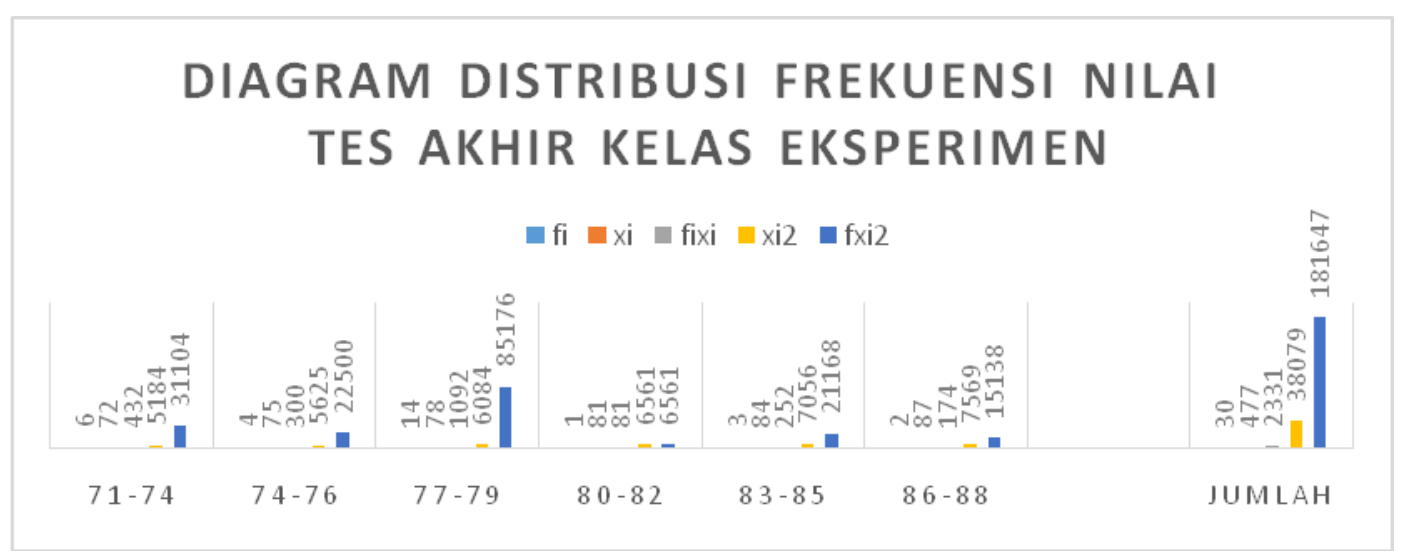

Berdasarkan hasil pengujian hipotesis dengan menggunakan rumus uji-t, diperoleh $t_{\text {hitung }}=3,50$ dan $t_{\text {tabel }} 1,6991$. Dengan demikian berarti $t_{\text {hitung }} \geq t_{\text {tabel }}$ sehingga $H_{0}$ ditolak dan $H_{a}$ diterima yang artinya "Ada pengaruh yang signifikan dari strategi writing in the here and now" terhadap kemampuan menulis argumentasi siswa kelas X SMK Madyatama Palembang. Berdasarkan data hasil penelitian yang dilakukan peneliti dari pertemuan pertama sampai pertemuan terakhir melalui pembelajaran menggunakan strategi writing in the here and now di SMK Madyatama Palembang, pengaruh strategi writing in the here and now terhadap kemampuan menulis argumentasi siswa kelas X SMK Madyatma Palembang dikategorikan sedang. Hal ini dapat dilihat dari perolehan data mengenai nilai hasil belajar siswa sebelum dan sesudah mendapatkan pembelajaran menggunakan strategi writing in the here and now, peneliti melihat 
adanya peningkatan hasil belajar siswa setiap kali pertemuan pembelajaran yang dilihat dari perolehan nilai soal latihan siswa.

Setelah menghitung nilai normalitas dan hipotesis dari hasil perhitungan terbukti berdistribusi normal, maka data tersebut dapat diolah dengan uji statistik yaitu dengan uji-t satu fihak. Dari hasil perhitungan uji-t diperoleh nilai $t_{\text {hitung }}=$ 3,50 dan $t_{\text {tabel }} 1$,6991. Dengan demikian berarti $t_{\text {hitung }} \geq t_{\text {tabel }}$ sehingga $H_{0}$ ditolak dan $H_{a}$ diterima. Hal itu menunjukkan adanya pengaruh strategi writing in the here and now terhadap kemampuan menulis argumentasi siswa kelas X SMK Madyatama Palembang. Di sisi lain, semuanya kembali kepada siswa dan guru. Hal yang teramat penting adalah siswa serta guru sebaiknya memiliki motivasi dan kondisi yang memungkinkan untuk pembelajaran dalam kelas (Hermansyah, 2016:41).

Selanjutnya Armariena (2015:371) mengungkapkan pembelajaran menulis argumentasi memerlukan strategi yang membantu siswa mengeluarkan pendapat. Penelitian Armariena menggunakan strategi Herringbone dan hasilnya sama-sama berpengaruh positif terhadap hasil belajar menulis argumentasi.

\section{SIMPULAN}

Dari hasil penelitian dan pembahasan yang telah dikemukakan, dapat disimpulkan sebagai berikut.

a. Ada pengaruh strategi writing in the here and now terhadap kemampuan menulis argumentasi siswa kelas X SMK Madyatama Palembang.

b. Berdasarkan hasil tes diperoleh nilai rata-rata siswa kelas eksperimen setelah menggunakan strategi writing in the here and now adalah 77,7. Hal ini menunjukkan bahwa variasi mengajar dengan menggunakan strategi writing in the here and now dapat meningkatkan hasil belajar siswa. 
Pengaruh Strategi Writing...(Hermansyah)

\section{DAFTAR PUSTAKA}

Armariena, D. N. (2015). Pengaruh Strategi Herringbone dan Kemampuan Berpikir Kritis terhadap Kemampuan Menulis Karangan Argumentasi Siswa Kelas VII SMP Negeri 45 Palembang. Kumpulan Jurnal Dosen Universitas PGRI Palembang Edisi 7, 369-378. Palembang: Universitas PGRI Palembang.

Armariena, D. N. dan Liza M. (2017). Penulisan Cerpen Berbasis Kearifan Lokal Sumatera Selatan dengan Metode Image Streaming dalam Proses Kreatif Mahasiswa. Jurnal PEMBAHSI (Online). Volume 7 Nomor 1:97-103. PPs Universitas PGRI Palembang.

Hermansyah. (2016). Language Learning Strategies Used by the Sixth Semester Students of English Education Study Program. English Empower Journal. Universitas Taman Siswa Palembang.

Kusumaningsih, dkk. (2013). Terampil Berbahasa Indonesia. Yogyakarta: Andi.

Semi, A. (2007). Dasar-Dasar Keterampilan Menulis. Bandung: Angkasa.

Silberman, M. L. (2016). Active Learning. Bandung: NuansaCendekia.

Sugiyono. (2016). Metode Penelitian Pendidikan. Bandung: Alfabeta. 